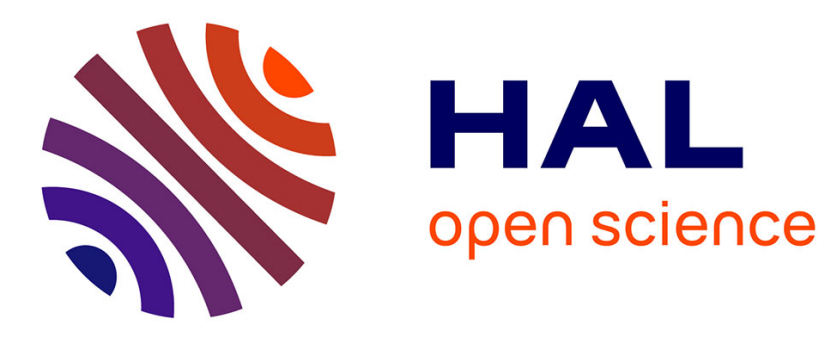

\title{
Monitoring DNA-Ligand Interactions in Living Human Cells Using NMR Spectroscopy
}

\author{
Michaela Krafcikova, Simon Dzatko, Coralie Caron, Anton Granzhan, \\ Radovan Fiala, Tomas Loja, Marie-Paule Teulade-Fichou, Tomas Fessl, \\ Robert Hansel-Hertsch, Jean-Louis Mergny, et al.
}

\section{To cite this version:}

Michaela Krafcikova, Simon Dzatko, Coralie Caron, Anton Granzhan, Radovan Fiala, et al.. Monitoring DNA-Ligand Interactions in Living Human Cells Using NMR Spectroscopy. Journal of the American Chemical Society, 2019, 141 (34), pp.13281-13285. 10.1021/jacs.9b03031 . hal-02344480

\author{
HAL Id: hal-02344480 \\ https://hal.science/hal-02344480
}

Submitted on 6 Nov 2019

HAL is a multi-disciplinary open access archive for the deposit and dissemination of scientific research documents, whether they are published or not. The documents may come from teaching and research institutions in France or abroad, or from public or private research centers.
L'archive ouverte pluridisciplinaire HAL, est destinée au dépôt et à la diffusion de documents scientifiques de niveau recherche, publiés ou non, émanant des établissements d'enseignement et de recherche français ou étrangers, des laboratoires publics ou privés. 


\title{
Monitoring DNA-Ligand Interactions in Living Human Cells Using NMR Spectroscopy
}

\author{
Michaela Krafcikova, ${ }^{\dagger, \#, \nabla}$ Simon Dzatko, ${ }^{\dagger, \nabla}$ Coralie Caron, ${ }^{\dagger, \S}$ Anton Granzhan, ${ }^{\dagger, \S \odot ~ R a d o v a n ~ F i a l a, ~}{ }^{\dagger}$ \\ Tomas Loja, ${ }^{\dagger}$ Marie-Paule Teulade-Fichou, ${ }^{\ddagger},{ }^{\prime}$ Tomas Fessl, ${ }^{\|}$Robert Hänsel-Hertsch, ${ }^{\perp}$

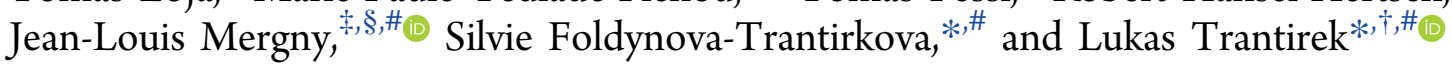

${ }^{\dagger}$ Central European Institute of Technology, Masaryk University, Brno 62500, Czech Republic

"CNRS UMR9187, INSERM U1196, Institut Curie, PSL Research University, Orsay 91405, France

${ }^{\S}$ CNRS UMR9187, INSERM U1196, Université Paris Sud, Université Paris Saclay, Orsay 91405, France

"Faculty of Science, University of South Bohemia, Ceske Budejovice CZ-370 05, Czech Republic

${ }^{\perp}$ Cancer Research UK Cambridge Institute, University of Cambridge, Cambridge CB2 ORE, United Kingdom

${ }^{\#}$ Institute of Biophysics, v.v.i., ASCR, Brno 62500, Czech Republic

\section{Supporting Information}

ABSTRACT: Studies on DNA-ligand interactions in the cellular environment are problematic due to the lack of suitable biophysical tools. To address this need, we developed an in-cell NMR-based approach for monitoring DNA-ligand interactions inside the nuclei of living human cells. Our method relies on the acquisition of NMR data from cells electroporated with preformed DNA-ligand complexes. The impact of the intracellular environment on the integrity of the complexes is assessed based on in-cell NMR signals from unbound and ligandbound forms of a given DNA target. This technique was tested on complexes of two model DNA fragments and four ligands, namely, a representative DNA minor-groove binder (netropsin) and ligands binding DNA base-pairing defects (naphthalenophanes). In the latter case, we demonstrate that two of the three in vitro-validated ligands retain their ability to form stable interactions with their model target DNA in cellulo, whereas the third one loses this ability due to off-target interactions with genomic DNA and cellular metabolites. Collectively, our data suggest that direct evaluation of the behavior of druglike molecules in the intracellular environment provides important insights into the development of DNA-binding ligands with desirable biological activity and minimal side effects resulting from off-target binding.

$\mathrm{D}$ NA is an important target for drug design and development. ${ }^{1}$ Thus far, the development of DNAbinding ligands has relied on data from in vitro biophysical assays, in vivo or in cellulo biological assays, or in silico structure-based DNA-targeting approaches. While biological assays are indispensable for evaluating the biological effects of ligands, their principal disadvantage is the difficulty in connecting the ligand-induced biological effects to the direct action of the ligand on its putative DNA target. In contrast, both in vitro and in silico approaches are based on the quantitative characterization of a simple two-component
(DNA-ligand) system under non-native conditions. They allow characterization of the DNA-ligand complex in terms of either the structure or quantitative parameters such as the thermodynamic stability of the complex and the kinetics of its formation. $^{2-10}$ Notably, both in vitro and in silico approaches provide information on DNA-ligand interactions in the absence of the cellular environment. As a consequence, ligand properties determined under these conditions do not automatically reflect the efficacy that the ligands display in vivo, where the presence of alternative targets and various environmental factors can influence the formation and stability of DNA-ligand complexes. Undoubtedly, the development of novel tools allowing direct evaluation of drug-target interactions under complex conditions in living cells is of general interest. Here, we elaborate on the recently introduced electroporation concept devised for proteins ${ }^{11}$ and nucleic acids $^{12}$ and extend this approach to characterizing DNAligand interactions in the nuclei of living human cells.

The application of in-cell NMR spectroscopy for investigating DNA-ligand interactions was tested using two model systems comprising the complexes formed between (i) a 24-nt DNA hairpin (MH-DNA) and netropsin, a polyamide ligand representative of minor-groove DNA binders, ${ }^{13-15}$ and (ii) an 11-bp DNA duplex containing a $\mathrm{T} \cdot \mathrm{T}$ mismatch (TT-DNA) and a set of three substituted naphthalenophanes 1-3, which are representative of drugs targeting DNA base-pairing defects (Figure 1). ${ }^{16,17}$ These models were chosen because, beyond their potential therapeutic importance, ${ }^{15,16}$ the NMR signals of their ligand-bound and unbound DNA targets are clearly distinct, making them well suited for a proof-of-principle demonstration of the in-cell NMR approach. First, we evaluated the efficacy of electroporation-based delivery of the NMR substrate. Notably, two-step delivery of a ligand and its DNA target to cells via two sequential electroporation procedures resulted in high cell mortality and/or DNA leakage from cells independent of the order of component delivery (i.e., DNA

Received: March 19, 2019

Published: August 9, 2019 
A

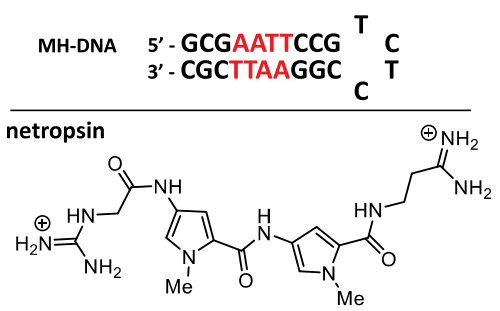

B

TT-DNA 5' - CGTCGTAGTGC - 3' 3' - GCAGCTTCACG - 5'

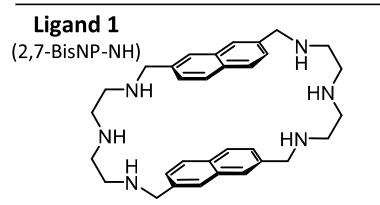

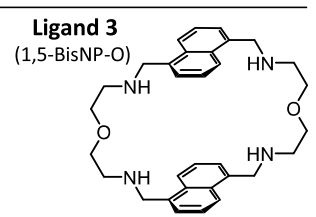

Figure 1. Schematic representations of the DNA targets and DNA-binding ligands used in the present study. (A) Netropsin and its model target, hairpin-based DNA (MH-DNA). (B) Three substituted naphthalenophanes and their model target, T·T mismatch-containing DNA (TT-DNA). Ligand binding sites are indicated in red.

and ligand ) (Figure $\mathrm{S} 1 \mathrm{~A}-\mathrm{C}$ ). In contrast, the delivery of complexes preformed in the electroporation (EC) buffer proved to be highly effective (Figure S1D): The complexes were introduced into more than $92 \%$ of cells at concentrations sufficient for their detection by NMR (Figures 2 and S2).

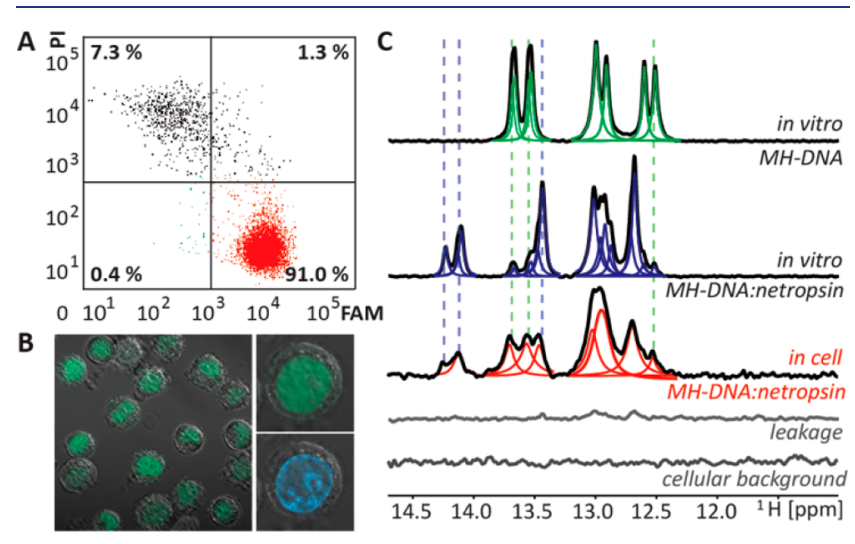

Figure 2. Double-staining (PI/FAM) FCM analysis (A) and confocal microscopy images (B) of cells cotransfected with the (FAM)-MHDNA:netropsin (1:1) complex. In panel (A), the percentages of viable nontransfected cells, viable MH-DNA containing cells, dead/ compromised nontransfected cells, and dead/compromised transfected cells are indicated in the bottom-left, bottom-right, top-left, and top-right quadrants, respectively. In panel (B), the green color marks the localization of (FAM)-MH-DNA, while the blue color marks cell nuclei stained with Hoechst 33342. (C) Deconvoluted imino regions of $1 \mathrm{D}{ }^{1} \mathrm{H}$ NMR spectra of MH-DNA in vitro and the 1:1 MHDNA:netropsin complex in vitro and in cells. NMR spectra of extracellular fluid taken from the sample after in-cell NMR spectral acquisition and of nontransfected cells (cellular background) are shown in gray. The vertical green and blue dashed lines mark imino signals specific to the unbound and ligand-bound forms of MH-DNA, respectively.

Importantly, among the cells transfected with the complexes (i.e., those contributing to the in-cell NMR signals), over $98 \%$ remained viable after the time required for the acquisition of NMR spectra (Figure S2).

Moreover, confocal microscopy confirmed that the delivered DNA was localized in the nuclei (Figures 2 and S2), and a time-resolved membrane leakage experiment and the comparable line widths between the in vitro and in-cell NMR spectra indicated that this DNA was freely tumbling (Figures S3 and S4). Most importantly, the imino region of the NMR spectrum of a suspension of nontransfected cells showed no signals (Figures 2 and S5, Note S1), whereas NMR spectra of suspensions of cells transfected with DNA-ligand complexes displayed signals originating from the introduced DNA (Figures 2 and S2). The concentration of transfected complexes in the in-cell NMR samples was estimated as 10$15 \mu \mathrm{M}$ (Figure S5C). Notably, in all cases, DNA leakage from the cells was negligible, as demonstrated by the imino region of the NMR spectra of the extracellular fluid collected from the samples after the acquisition of in-cell NMR spectra (Figures 2 and S2).

The in-cell NMR spectra showed well-resolved signal patterns, which were compared with the in vitro NMR spectra of unbound DNA and DNA-ligand complexes. For the MHDNA:netropsin, TT-DNA:1, and TT-DNA:2 complexes, their in-cell NMR spectra corresponded to a superposition of the spectra of the ligand-bound and unbound DNA substrates (Figures 2, 3, and S2). However, for the TT-DNA:3 system, the in-cell NMR spectrum closely resembled that of the unbound DNA target (Figures 3, S2, and S6). Overall, the incell NMR data for the TT-DNA:ligand system suggested that, in contrast to DNA-ligand complexes under in vitro conditions, complexes in the presence of intracellular factors dissociated to an extent that was ligand dependent. To assess whether the differences in the dissociation level between the TT-DNA complexes of the three naphthalenophanes could be a consequence of their different efficiencies of delivery into cells or whether the in-cell NMR spectra instead reflected real differences in the capacity of the individual ligands to bind TTDNA in the cellular environment, we employed three separate approaches. First, a mock electroporation experiment on the preformed TT-DNA:ligand complexes dissolved in EC buffer was performed: The application of high-voltage pulses (emulating the setup used for electroporation) did not affect the integrity of the individual complexes (Figure S7). Then, we delivered the DNA-ligand complexes into isolated intact nuclei while omitting the electroporation step. Notably, the NMR spectra of the complexes demonstrated only minor dissociation of the TT-DNA:1 complex; however, moderate and dramatic dissociation was observed in the nuclei containing TT-DNA:2 and TT-DNA:3 (Figure 3). The pattern of imino signals in the NMR spectrum of the TTDNA:3 system in intact nuclei was essentially identical to that of the in-cell NMR spectrum of ligand-free TT-DNA (Figure 3 and S6). These observations suggest that nuclear components are potential competitors for ligands $\mathbf{2}$ and, particularly, 3. To elaborate on this hypothesis, we acquired NMR spectra of TT-DNA:ligand complexes in the presence of calf thymus (ct) DNA to emulate the influence of genomic DNA. The presence of ctDNA resulted in a shift in TT-DNA from its ligand-bound form toward the unbound form, which was particularly pronounced for the TT-DNA:3 complex (Figure S8). These results suggest that dissociation of the complex observed in the intact cells and intact cell nuclei can, at least partly, be attributed to ligand binding to alternative 


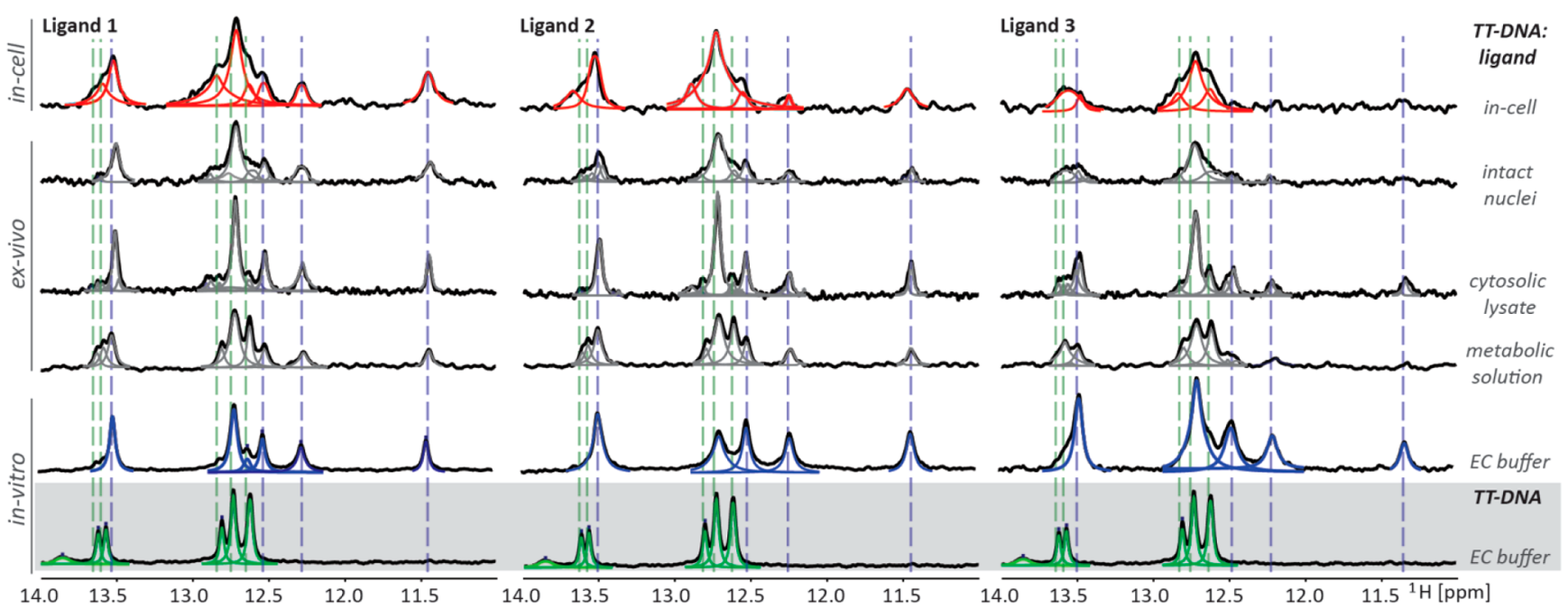

Figure 3. Deconvoluted imino regions of $1 \mathrm{D}{ }^{1} \mathrm{H}$ NMR spectra of TT-DNA in EC buffer and the TT-DNA:ligand complexes in-cell, ex vivo (intact nuclei/cytosolic lysate/metabolic solution), and in EC buffer (in vitro). The vertical green and blue dashed lines mark imino signals specific to the unbound and ligand bound forms of TT-DNA, respectively. For controls of the in-cell NMR measurements, see Figure S2.

sites in the genomic DNA, which is in line with the properties of naphthalenophanes previously observed in vitro. In fact, while the three ligands share similar physicochemical properties, ligand 3, which has a different topology, nonspecifically binds to double-stranded DNA much more strongly than do ligands $\mathbf{1}$ and $\mathbf{2}^{16,18}$ Finally, we recorded NMR spectra of individual complexes dissolved in cytosolic lysate and in a solution of cellular metabolites, corresponding to the lowmolecular-weight cellular fraction prepared from the acetonitrile extract of nontransfected cells (Supporting Information, Material and Methods). The acquired spectra of the cytosolic lysate were dominated by signals specific to the formed complexes (Figure 3); however, low-intensity imino signals from unbound TT-DNA were also present, suggesting that some components in the cytosolic environment slightly impact the integrity of individual complexes.

Remarkably, the most pronounced changes in the spectral patterns of all the complexes were observed in the presence of cellular metabolites (Figure 3). While the spectra of the TTDNA: 1 and TT-DNA:2 complexes in the metabolite solution showed signals of comparable intensity from both unbound and ligand-bound TT-DNA, the corresponding NMR spectrum of the TT-DNA:3 complex was dominated by signals from unbound TT-DNA (Figure 3). The latter observation suggests substantial dissociation of the TT-DNA:3 complex in the presence of metabolites. The capacity of metabolites to act as off-targets for ligands was subsequently confirmed using an NMR titration experiment, in which the metabolic solution was titrated with individual ligands at various concentrations (50 and $100 \mu \mathrm{M}$ ). Ligand- and concentration-dependent changes in the positions and intensities of NMR signals from several metabolites, such as ATP, cAMP, GMP, and fumarate, were indicative of ligand-metabolite binding (Figure S9). Accordingly, in vitro NMR spectra of 1:1 mixtures of ligands with these metabolites confirmed their capacity to interact with the ligands (Figure S10). Altogether, the ex vivo NMR measurements showed that the presence of both metabolic and nuclear components might promote the dissociation of TT-DNA:ligand complexes; however, the extent of this effect was ligand dependent.
To summarize, we demonstrated that DNA-ligand complexes can be monitored in the nuclei of living human cells using NMR spectroscopy. Analysis of in-cell NMR spectra using the spectral fingerprint concept ${ }^{19}$ reveals whether-and to what extent-the intracellular components and the environment of living cells influence the stability of these complexes. For the TT-DNA:ligand model systems, we identified the nature of the cellular components susceptible to act as off-targets and disrupt the DNA-ligand complexes and confirmed that the dissociation of individual complexes evidenced by in-cell NMR spectra was primarily due to the influence of these factors and not an artifact of the electroporation process.

The in-cell NMR measurement can be considered a sophisticated competitive binding experiment performed under physiological conditions, where the model target DNA inserted into cells in excess competes for the ligand with everything else in the cell and where the stabilities of DNA:ligand complexes are affected by nonspecific intracellular environmental factors such as crowding, water activity, dielectric permittivity, or local ionic concentration. These conditions are specific to the intracellular environment of intact cells: They are not replicated in cellular lysates/fractions, and they cannot be reliably emulated in vitro, as illustrated by the conflicting results obtained from measurements of the TTDNA: 1, 2, and 3 complexes in the presence of either PEG200 or Ficoll 70, most commonly used mimics of molecular crowding ${ }^{20-23}$ and conditions of reduced dielectric permittivity in the intracellular space (Figure S11). ${ }^{24-26}$ In that respect, the in-cell NMR experiments are particularly suited for validation of ligands that, after being identified as promising candidates by in vitro screening assays, maintain or even reinforce their ability to bind to the target DNA in cells, thereby justifying their further development.

As with other currently available approaches for highresolution structural analysis of DNA, the presented method provides only information on the behavior of short DNA fragments. In other words, the in-cell NMR data do not reflect the influence of chromatin context or packing. However, the fact that DNA-binding ligands generally do not act on closed chromatin but rather during processes involving its open state, 
such as transcription and replication, provides justification for the use of our system as a model replicating the effect of DNAtargeting ligands in vivo. Furthermore, the presented approach can be directly extended to RNA-based targets. The approach is also invariant of isotopic or chemical labeling of the sample and can be directly adapted for analysis of RNA/DNA:ligand complexes using in-cell $\mathrm{EPR}^{27-29}$ and in-cell single particle FRET. $^{30}$

\section{ASSOCIATED CONTENT}

\section{(S Supporting Information}

The Supporting Information is available free of charge on the ACS Publications website at DOI: 10.1021/jacs.9b03031.

Experimental Section, material and methods, Figures S1-S11, and Note S1 (PDF)

\section{AUTHOR INFORMATION}

\section{Corresponding Authors}

*silvie.trantirkova@ceitec.muni.cz

*lukas.trantirek@ceitec.muni.cz

\section{ORCID}

Anton Granzhan: 0000-0002-0424-0461

Jean-Louis Mergny: 0000-0003-3043-8401

Lukas Trantirek: 0000-0001-5948-4837

\section{Author Contributions}

$\nabla_{\text {These authors contributed equally. }}$

\section{Notes}

The authors declare no competing financial interest.

\section{ACKNOWLEDGMENTS}

We thank P. Selenko and P. Theillet for helpful discussions regarding the electroporation method. MEYS is also acknowledged for their support of access to research infrastructure (CEITEC 2020 LQ1601; CIISB-LM2015043; Czech-BioImaging LM2015062; EATRIS-CZ LM2015064; CZ.02.1.01/0.0/ $0.0 / 15003 / 0000441)$ and for their support of students' mobility (8J18FR001). This project was supported by grants from the Czech Science Foundation (16-10504S and 1926041X), the Grant Agency of Masaryk University (MUNI/E/ 0771/2018), iNEXT (grant agreement 653706) funded by the Horizon 2020 Programme, the "IDI 2016" project funded by the French National Research Agency (ANR-11-IDEX-000302), and project SYMBIT (CZ.02.1.01/0.0/15_003/0000477) funded by the European Regional Development Fund and Ministry of Education, Youth, and Sports (MEYS) of the Czech Republic.

\section{REFERENCES}

(1) Imming, P.; Sinning, C.; Meyer, A. Drugs, Their Targets and the Nature and Number of Drug Targets. Nat. Rev. Drug Discovery 2006, 5 (10), 821-834.

(2) Dailey, M. M.; Hait, C.; Holt, P. A.; Maguire, J. M.; Meier, J. B.; Miller, M. C.; Petraccone, L.; Trent, J. O. Structure-Based Drug Design: From Nucleic Acid to Membrane Protein Targets. Exp. Mol. Pathol. 2009, 86 (3), 141-150.

(3) Holt, P. A.; Ragazzon, P.; Strekowski, L.; Chaires, J. B.; Trent, J. O. Discovery of Novel Triple Helical DNA Intercalators by an Integrated Virtual and Actual Screening Platform. Nucleic Acids Res. 2009, 37 (4), 1280-1287.

(4) Murat, P.; Singh, Y.; Defrancq, E. Methods for Investigating GQuadruplex DNA/Ligand Interactions. Chem. Soc. Rev. 2011, 40 (11), 5293-5307.
(5) Ma, D.-L.; Chan, D. S.-H.; Lee, P.; Kwan, M. H.-T.; Leung, C.H. Molecular Modeling of Drug-DNA Interactions: Virtual Screening to Structure-Based Design. Biochimie 2011, 93 (8), 1252-1266.

(6) Cosconati, S.; Rizzo, A.; Trotta, R.; Pagano, B.; Iachettini, S.; De Tito, S.; Lauri, I.; Fotticchia, I.; Giustiniano, M.; Marinelli, L.; Giancola, C.; Novellino, E.; Biroccio, A.; Randazzo, A. Shooting for Selective Druglike G-Quadruplex Binders: Evidence for Telomeric DNA Damage and Tumor Cell Death. J. Med. Chem. 2012, 55 (22), 9785-9792.

(7) Garbett, N. C.; Chaires, J. B. Thermodynamic Studies for Drug Design and Screening. Expert Opin. Drug Discovery 2012, 7 (4), 299314

(8) Pagano, B.; Cosconati, S.; Gabelica, V.; Petraccone, L.; De Tito, S.; Marinelli, L.; La Pietra, V.; di Leva, F. S.; Lauri, I.; Trotta, R.; Novellino, E.; Giancola, C.; Randazzo, A. State-of-the-Art Methodologies for the Discovery and Characterization of DNA G-Quadruplex Binders. Curr. Pharm. Des. 2012, 18 (14), 1880-1899.

(9) Sheng, J.; Gan, J.; Huang, Z. Structure-Based DNA-Targeting Strategies with Small Molecule Ligands for Drug Discovery. Med. Res. Rev. 2013, 33 (5), 1119-1173.

(10) Snyder, R. D.; Holt, P. A.; Maguire, J. M.; Trent, J. O. Prediction of Noncovalent Drug/DNA Interaction Using Computational Docking Models: Studies with over 1350 Launched Drugs. Environ. Mol. Mutagen. 2013, 54 (8), 668-681.

(11) Theillet, F.-X.; Binolfi, A.; Bekei, B.; Martorana, A.; Rose, H. M.; Stuiver, M.; Verzini, S.; Lorenz, D.; van Rossum, M.; Goldfarb, D.; Selenko, P. Structural Disorder of Monomeric $\alpha$-Synuclein Persists in Mammalian Cells. Nature 2016, 530 (7588), 45-50.

(12) Dzatko, S.; Krafcikova, M.; Hänsel-Hertsch, R.; Fessl, T.; Fiala, R.; Loja, T.; Krafcik, D.; Mergny, J.-L.; Foldynova-Trantirkova, S.; Trantirek, L. Evaluation of the Stability of DNA I-Motifs in the Nuclei of Living Mammalian Cells. Angew. Chem., Int. Ed. 2018, 57 (8), 2165-2169.

(13) Bailly, C.; Chaires, J. B. Sequence-Specific DNA Minor Groove Binders. Design and Synthesis of Netropsin and Distamycin Analogues. Bioconjugate Chem. 1998, 9 (5), 513-538.

(14) Dervan, P. B.; Edelson, B. S. Recognition of the DNA Minor Groove by Pyrrole-Imidazole Polyamides. Curr. Opin. Struct. Biol. 2003, 13 (3), 284-299.

(15) Kawamoto, Y.; Bando, T.; Sugiyama, H. Sequence-Specific DNA Binding Pyrrole-Imidazole Polyamides and Their Applications. Bioorg. Med. Chem. 2018, 26 (8), 1393-1411.

(16) Granzhan, A.; Largy, E.; Saettel, N.; Teulade-Fichou, M.-P. Macrocyclic DNA-Mismatch-Binding Ligands: Structural Determinants of Selectivity. Chem. - Eur. J. 2010, 16 (3), 878-889.

(17) Jourdan, M.; Granzhan, A.; Guillot, R.; Dumy, P.; TeuladeFichou, M.-P. Double Threading through DNA: NMR Structural Study of a Bis-Naphthalene Macrocycle Bound to a ThymineThymine Mismatch. Nucleic Acids Res. 2012, 40 (11), 5115-5128.

(18) Kotera, N.; Granzhan, A.; Teulade-Fichou, M.-P. Comparative Study of Affinity and Selectivity of Ligands Targeting Abasic and Mismatch Sites in DNA Using a Fluorescence-Melting Assay. Biochimie 2016, 128-129, 133-137.

(19) Hänsel, R.; Foldynová-Trantírková, S.; Dötsch, V.; Trantírek, L. Investigation of Quadruplex Structure under Physiological Conditions Using In-Cell NMR. Top. Curr. Chem. 2012, 330, 47-65.

(20) Hancock, R. Crowding, Entropic Forces, and Confinement: Crucial Factors for Structures and Functions in the Cell Nucleus. Biochemistry 2018, 83 (4), 326-337.

(21) Nakano, S.; Miyoshi, D.; Sugimoto, N. Effects of Molecular Crowding on the Structures, Interactions, and Functions of Nucleic Acids. Chem. Rev. 2014, 114 (5), 2733-2758.

(22) Nakano, S.; Sugimoto, N. Model Studies of the Effects of Intracellular Crowding on Nucleic Acid Interactions. Mol. BioSyst. 2017, 13 (1), 32-41.

(23) Nakano, S.-I.; Sugimoto, N. The Structural Stability and Catalytic Activity of DNA and RNA Oligonucleotides in the Presence of Organic Solvents. Biophys. Rev. 2016, 8 (1), 11-23. 
(24) Gupta, S.; Alargova, R. G.; Kilpatrick, P. K.; Velev, O. D. OnChip Electric Field Driven Assembly of Biocomposites from Live Cells and Functionalized Particles. Soft Matter 2008, 4 (4), 726-730.

(25) Zaslavsky, B. Y.; Miheeva, L. M.; Rodnikova, M. N.; Spivak, G. V.; Harkin, V. S.; Mahmudov, A. U. Dielectric Properties of Water in the Coexisting Phases of Aqueous Polymeric Two-Phase Systems. J. Chem. Soc., Faraday Trans. 1 1989, 85 (9), 2857-2865.

(26) Zaslavsky, B. Y.; Miheeva, L. M.; Masimov, E. A.; Djafarov, S. F.; Reichardt, C. Solvent Polarity of Aqueous Polymer Solutions as Measured by the Solvatochromic Technique. J. Chem. Soc., Faraday Trans. 1990, 86 (3), 519-524.

(27) Giassa, I.-C.; Rynes, J.; Fessl, T.; Foldynova-Trantirkova, S.; Trantirek, L. Advances in the Cellular Structural Biology of Nucleic Acids. FEBS Lett. 2018, 592 (12), 1997-2011.

(28) Krstić, I.; Hänsel, R.; Romainczyk, O.; Engels, J. W.; Dötsch, V.; Prisner, T. F. Long-Range Distance Measurements on Nucleic Acids in Cells by Pulsed EPR Spectroscopy. Angew. Chem., Int. Ed. 2011, 50 (22), 5070-5074.

(29) Azarkh, M.; Okle, O.; Singh, V.; Seemann, I. T.; Hartig, J. S.; Dietrich, D. R.; Drescher, M. Long-Range Distance Determination in a DNA Model System inside Xenopus Laevis Oocytes by in-Cell SpinLabel EPR. ChemBioChem 2011, 12 (13), 1992-1995.

(30) Fessl, T.; Adamec, F.; Polivka, T.; Foldynova-Trantirkova, S.; Vacha, F.; Trantirek, L. Towards Characterization of DNA Structure under Physiological Conditions in Vivo at the Single-Molecule Level Using Single-Pair FRET. Nucleic Acids Res. 2012, 40 (16), e121. 